\title{
RELATIONSHIP SUPERVISION SYSTEM OF HYGIENE SANITATION WITH FOOD QUALITY IN AIR TRANSPORTATION AND CATERING BUSINESS IN MEDAN
}

\author{
Zaitun \\ ${ }^{1}$ Food Production Lecturer of Medan Tourism Academy \\ Medan, Indonesia \\ zaitundjamal@gmail.com
}

\author{
Andora Jusuf Ahmad ${ }^{2}$ \\ ${ }^{2}$ Food Production Lecturer of Medan Tourism Academy \\ Medan, Indonesia
}

\begin{abstract}
This objective of this study was to analyze the relationship supervision system of hygiene sanitation with food quality in air transportation and catering business in Medan. This research used Cross Sectional study design with a population of 67 people of food tester and the population sampled in this study. Primary data collection technique have done by three ways, there were interviews with a questionnaire, observation and laboratory tests. Data analysis method used Chi-square test. Result indicated that there was $E$ coli of $240 / 100 \mathrm{ml}$, iron. $0,38-0,45,0,24-0,31$ aluminum, Barium 0,79-0,81 at rendang and drinking water at catering business. Catering physical condition in two (2) industry air transportation catering already meet the standards but in the physical feasibility of the three (3) industry catering order has not been feasible. Recommendation of this study were catering industry need control system and formed partnership with other institutions of the control system and managers must be aware that food does not become a mediator of disease and food poisoning.
\end{abstract}

Keywords- air transportation, catering business, food quality, hygiene sanitation, supervision system

\section{INTRODUCTION}

Catering industrial sector is currently very much standing, because not all industries that need the service is able to manage in the industry. They consider the management of catering services is specific and requires its own competence. Many industries cooperating with catering such as hospitals, hotels, offices, airlines and others.

Catering industry in cooperation usually associated with the part or parts of the kitchen of the restaurant industry who request it in terms of the management of food and beverage service and drinks. Part kitchen (food production) is one part of which is included in the business catering, where catering are companies or individuals who conduct food processing and beverages served outside business premises on the basis of orders.

Food and beverage processing industry catering services should be kept particularly in terms of the cleanliness of the work environment as it can be one source of breeding grounds for bacteria that can cause disease and is a mediator of microbial contamination causes food poisoning and beverages.

The principles of organization of food and beverage hygiene should be managed properly, a good management system starting from the procurement system of food and beverage raw materials, storage of foodstuffs and beverages, transportation, food and beverages, serving food and drinks, free from toxic materials, has certification both for personnel and certification. In addition to the management principle it is necessary also standard on the physical fulfillment of the kitchen such as: the location of the building, the condition of the walls and mopping floors, ceilings, lighting, processing rooms, washing facilities equipment, availability of water, availability of bins and bathroom / toilet. The importance of food and beverage management in accordance with the principles of hygiene in order to be consumed and beneficial for the body and do not transmit disease or illness as a conductor media source. In addition, the lack of hygiene and sanitation of food can be a cause of food poisoning cases and drinks both in the home and industry.

In Indonesia provisions concerning the sanitation and hygiene of food and beverage contained in health minister's rule number 715 in 2003. In the health minister's rule has been determined that the sanitary hygiene requirements include location, building and facilities are comprised of pages, the construction of floors, walls, sky - sky, doors and windows, lighting, ventilation, food and beverage processing rooms, washing facilities and equipment, food and beverages, hand washing facilities, clean water, toilets, showers.

Preliminary surveys conducted by researchers in May 2012 by taking secondary data in the Port Health Office of Air Polonia mentioned that there are currently as many as two (2) catering industry who is working with some of the aviation business. The industry has had a business license and a certificate of decent hygiene and sanitation. In addition the survey also conducted on 3 pieces catering industry in cooperation with the organizers of the party in the field but these efforts do not yet have decent sanitation hygiene certificate but have a business license.

Results of the survey through interviews of business owners said that they had never received complaints from customers about the results catering does. However, from the results of observations conducted by researchers showed that the food and beverage processing system which is done is still far from the requirement that it should be. Researchers saw that the system of provision of food and drink still less worthy to serve as the basis for the manufacture of food and beverage ingredients such as spices, vegetables withered, his unkempt where the raw material is still not implemented the separation and storage of food ingredients and specialty drinks and non-performance 
storage of foodstuffs and beverages should be in place to prevent contamination of food and drink from flies and splashes of other materials. Also in the kitchen are also found some things that are not worthy of such a management that does not meet the standards in accordance with the quantity and quality, there is still a lack of number of sinks and bathroom attendant, floors, and ceilings and walls that look soiled.

Observation of clothing kitchen personnel, researchers also found that some officers do not use special clothing and some of the officers who wear clothing also are not in accordance with the requirements. Still found officers who do not wear a hat and gloves in the work. According to them washing clothes is done 2 times a week. Given this, it can predict the development of bacteria in clothes that have been hit by splashes of food and beverages.

Based on the above authors are interested in doing research on catering business cooperation with companies that perform airport and the restaurant manager whether it meets hygiene and sanitation standards in accordance with the requirements of hygiene and sanitary food service that is already in the set according to health minister's rule number 715 in 2003 . From the description above background, the study aims to determine the relationship of surveillance systems with sanitation hygiene and quality of food on catering air transport and managers party in the city of Medan.

\section{RESEARCH METHODS}

This research is analytic with cross sectional design. This study was conducted in two (2) Industrial catering services that make cooperation with Polonia airport and 3 (three) managers party in the city of Medan. When the study for 6 months. The population in this study were all officers' industrial kitchens catering services in five (5) pieces of the food service industry, amounting to 67 people and the entire population to be sampled in this study.

\section{RESEACH RESULTS}

\section{A. Surveillance System}

Results of interviews conducted for 5 (five), indicating that the managing partner in the food service industry that has a certificate. In the implementation of the monitoring system are:

\begin{tabular}{|l|l|}
\hline \multicolumn{1}{|c|}{ MONITORING SYSTEMS } \\
\hline \multicolumn{1}{|c|}{$\begin{array}{c}\text { Certified Hospitality } \\
\text { Industry }\end{array}$} & \multicolumn{1}{c|}{$\begin{array}{c}\text { Not Certified Hospitality } \\
\text { Industry }\end{array}$} \\
\hline $\begin{array}{l}\text { Port Health Office conduct field } \\
\text { inspections of at least 2 (two) } \\
\text { times a year }\end{array}$ & Never Examination \\
\hline $\begin{array}{l}\text { Management license is still } \\
\text { active }\end{array}$ & $\begin{array}{l}\text { Management license is still } \\
\text { active }\end{array}$ \\
\hline $\begin{array}{l}\text { Tests conducted Airworthiness } \\
\text { At Food Samples }\end{array}$ & Never Do Test Airworthiness \\
\hline $\begin{array}{l}\text { There are regulations about } \\
\text { catering required and most } \\
\text { obeyed }\end{array}$ & $\begin{array}{l}\text { There are no regulations } \\
\text { concerning the provision of } \\
\text { catering services }\end{array}$ \\
\hline
\end{tabular}

\begin{tabular}{|l|l|l|}
\hline $\begin{array}{l}\text { The dismissal sanctions for } \\
\text { offenders }\end{array}$ & There is no doubt that bind \\
\hline $\begin{array}{l}\text { It followed several Point } \\
\text { Requirements }\end{array}$ & $\begin{array}{l}\text { Despite not having a certificate } \\
\text { and regulations but 2 of 3 food } \\
\text { service industry has to follow } \\
\text { some principles of hygiene and } \\
\text { sanitation }\end{array}$ \\
\hline
\end{tabular}

\section{B. Hygiene Food handlers}

Recapitulation shows that food handlers have hygiene in the category worthy of as much as 28 people $(41.8 \%)$, it is not feasible as many as 39 people (58.2\%).

Table 1. Respondents Frequency Distribution Airworthiness Hygiene Services Industry catering On Air Transportation and Catering Business in Medan

\begin{tabular}{cccc}
\hline No & $\begin{array}{c}\text { Hygiene of } \\
\text { food handlers }\end{array}$ & Number & Percent (\%) \\
\hline 1 & Worthy & 28 & 41,8 \\
2 & Less Worthy & 39 & 58,2 \\
\hline & Total & $\mathbf{6 7}$ & $\mathbf{1 0 0 , 0}$ \\
\hline
\end{tabular}

These results indicate that the employee in charge of the kitchen is not fully maintain the cleanliness and health. This condition also shows that employees are not able to support the cleanliness of an activity does.

Based on the observations of researchers for carrying out research in two (2) air transport industry, system monitoring performed by supervisors in food processing and food handlers already meet the personal hygiene of a food handler where the work using work clothes, nails short, do not use jewelry and do not smoke while processing food. While in the third party administrator industry less attention because it is a household industry. Managers tend not to think about work clothes and personal hygiene of workers, where workers do not wear a hat in the work and still have long nails, jewelry rings using hands and do not get used to using the tools in making processed food.

\section{Sanitation}

Results of research on the feasibility of sanitation, indicating the following results:

Table 2. Respondents Frequency Distribution Implement

Principles Airworthiness Sanitary Food Industry on Air Transportation and Catering Business in Medan

\begin{tabular}{cccc}
\hline No & Food Sanitation & Total & Percent (\%) \\
\hline 1 & Worthy & 30 & 44,8 \\
2 & Less Worthy & 37 & 55,2 \\
\hline & Total & $\mathbf{6 7}$ & $\mathbf{1 0 0 , 0}$ \\
\hline
\end{tabular}




\section{Physical Condition Kitchen}

Results of research on the physical condition of the kitchen of five (5) of food service businesses surveyed indicate that the two of catering business who have a certificate of eligibility standards almost entirely physical. The physical condition of the air transport industry in accordance with the observations can be explained researchers already meet the standards of airworthiness, where from the start until the receipt of foodstuff processed food ingredients have a room - separate room with facilities of its own and each - each, in one of the air transport industry catering even already implementing a system Hazard Analysis Critical Control Point (HACCP) for surveillance equipment in use as freezer and chiller storage of raw materials and processed food is always monitored the temperature every hour by using a special form so that the temperature of the device is very controlled and not causing material stored within them contaminated with bacteria. Unsuitable physical condition catering kitchen air transport is only visible from the floor and walls are still there dead corner, as well as the handling of equipment that should be relieved of the pest by at least $50 \mathrm{ppm}$ chlorine solution or hot water to 80 degrees Celsius has not done well.

As for the physical condition of the kitchen 3 catering business of the party still does not meet airworthiness standards where there is a union of food processing from preparation until the processing of food, ventilation in each room is not good so interfere with air circulation places food processing, floors and walls are not watertight and less clean.

Table 3. Distribution Observations Airworthiness Physical Condition Kitchen on Air Transportation and catering business in Medan

\begin{tabular}{|c|c|c|c|c|c|c|c|c|c|c|c|}
\hline \multirow{4}{*}{ No } & \multirow{4}{*}{$\begin{array}{l}\text { Physical Condition } \\
\text { Kitchen }\end{array}$} & \multicolumn{10}{|c|}{ Catering industry } \\
\hline & & \multicolumn{4}{|c|}{ Certificates Have } & \multicolumn{6}{|c|}{ Not Have Certificate } \\
\hline & & \multicolumn{2}{|c|}{ Ind. I } & \multicolumn{2}{|c|}{ Ind. II } & \multicolumn{2}{|c|}{ Ind I } & \multicolumn{2}{|c|}{ Ind II } & \multicolumn{2}{|c|}{ Ind III } \\
\hline & & EG & $\begin{array}{l}\text { IE } \\
\text { G }\end{array}$ & EG & IEG & EG & IEG & EG & IEG & EG & IEG \\
\hline 1 & $\begin{array}{l}\text { food processing room } \\
\text { separated from the other }\end{array}$ & $\sqrt{ }$ & & $\sqrt{ }$ & & & $\sqrt{ }$ & & $\sqrt{ }$ & & $\sqrt{ }$ \\
\hline 2 & $\begin{array}{l}\text { Ventilation / equipped with } \\
\text { a chimney }\end{array}$ & $\sqrt{ }$ & & $\sqrt{ }$ & & & $\sqrt{ }$ & & $\sqrt{ }$ & & $\sqrt{ }$ \\
\hline 3 & $\begin{array}{l}\text { Sewerage equipped with } \\
\text { grase trap before being } \\
\text { drained into the septic tank }\end{array}$ & $\sqrt{ }$ & & $\sqrt{ }$ & & & $\sqrt{ }$ & & $\sqrt{ }$ & & $\sqrt{ }$ \\
\hline 4 & $\begin{array}{c}\text { The floors and walls are no } \\
\text { dead angle }\end{array}$ & $\sqrt{ }$ & & $\sqrt{ }$ & & & $\sqrt{ }$ & & $\sqrt{ }$ & & $\sqrt{ }$ \\
\hline 5 & $\begin{array}{l}\text { Washing facility of strong } \\
\text { material, the surface is } \\
\text { smooth and easy to clean }\end{array}$ & $\sqrt{ }$ & & $\sqrt{ }$ & & & $\sqrt{ }$ & & $\sqrt{ }$ & & $\sqrt{ }$ \\
\hline 6 & $\begin{array}{l}\text { Equipment relieved of the } \\
\text { little pests her with } 50 \mathrm{ppm} \\
\text { chlorine solution or hot } \\
\text { water to } 80 \text { degrees Celsius }\end{array}$ & $\sqrt{ }$ & & $\sqrt{ }$ & & & $\sqrt{1}$ & & $\sqrt{ }$ & & $\sqrt{ }$ \\
\hline 7 & $\begin{array}{l}\text { Equipped } 1 \text { (one) hand } \\
\text { washing which is attached } \\
\text { right near the entrance to } \\
\text { each room. }\end{array}$ & $\sqrt{ }$ & & $\sqrt{ }$ & & & $\sqrt{ }$ & & $\sqrt{ }$ & & $\sqrt{ }$ \\
\hline 8 & $\begin{array}{l}\text { Place cooked food separate } \\
\text { from cooked food } \\
\text { preparation. }\end{array}$ & $\sqrt{ }$ & & $\sqrt{ }$ & & $\sqrt{ }$ & & $\sqrt{ }$ & & & $\sqrt{ }$ \\
\hline 9 & $\begin{array}{l}\text { There are refrigerators that } \\
\text { reaches a temperature of } 10 \\
\text { degrees Celsius to - } 5 \\
\text { degrees Celsius. }\end{array}$ & $\sqrt{ }$ & & $\sqrt{ }$ & & $\sqrt{ }$ & & $\sqrt{ }$ & & $\sqrt{ }$ & \\
\hline 10 & $\begin{array}{c}\text { There are food transport } \\
\text { vehicles that have covered } \\
\text { construction. }\end{array}$ & $\sqrt{ }$ & & $\sqrt{ }$ & & $\sqrt{ }$ & & & $\sqrt{ }$ & $\sqrt{ }$ & \\
\hline
\end{tabular}


Specification:

Ind. I = The air transport industry 1 (a certificate)

Ind. II $=$ The air transport industry 2 (a certificate)

Ind. I = Catering Business I (do not have the certificate)

Ind. II $=$ Catering Business 2 (do not have the certificate)

Ind. III = Catering Business 3 (do not have the certificate)

$\mathrm{EG}=$ Eligible

IEG $=$ Ineligible

\section{E. Quality of food}

The results showed that the quality of food on catering air transport ( 2 catering industry) is in the category of Feasibility for numeric criteria E coli bacteria in food $0 / \mathrm{g}$ food sample., The numbers of bacteria $\mathrm{E}$ coli in beverages $0 / \mathrm{g}$ sample drinks. Total heavy metal content does not exceed a threshold ( 0$)$, and the amount of pesticide residues do not exceed a threshold (0). As for the food service industry that does not have a certificate obtained from three (3) food service industry that is less worthy of sanitary hygiene. Figures not found E. coli bacteria in food 0 / g sample the food, but found E coli in instances where the drinks in catering I: $240 / 100 \mathrm{ml}$, catering II: $38 / 100 \mathrm{ml}$, catering III: $96 / 100 \mathrm{ml}$. for the value of the iron content in the catering I: 0.4 , catering II: 0.45 , catering III: 0.38 . The content of aluminum was found in catering I: 0.25 , catering II: 0.31 , catering III: 0.24 . As for the content of barium in catering I: 0, catering II: 0.81 , catering III: 0.79 .

Table 4. Distribution of Airworthiness Standards Based on the Food Quality Service Industry on Air Transportation and Catering business in Medan

\begin{tabular}{|c|c|c|c|c|c|c|c|c|c|c|c|}
\hline \multirow{4}{*}{ No } & \multirow{4}{*}{ Quality of food } & \multicolumn{10}{|c|}{ Catering industry } \\
\hline & & \multicolumn{4}{|c|}{ has Certificates } & \multicolumn{6}{|c|}{ Having no Certificate } \\
\hline & & \multicolumn{2}{|c|}{ Ind. I } & \multicolumn{2}{|c|}{ Ind. II } & \multicolumn{2}{|c|}{ Ind I } & \multicolumn{2}{|c|}{ Ind II } & \multicolumn{2}{|c|}{ Ind III } \\
\hline & & Yes & No & Yes & No & Yes & No & Yes & No & Yes & No \\
\hline 1 & $\begin{array}{c}\text { Figures } E \text { coli bacteria } \\
\text { in beverages } 0 / \mathrm{g} \\
\text { sample drinks }\end{array}$ & & 0 & & 0 & $\begin{array}{l}240 / 1 \\
00 \mathrm{ml}\end{array}$ & & $\begin{array}{c}38 / \\
100 \mathrm{~m} \\
1\end{array}$ & & $\begin{array}{c}96 / \\
100 \mathrm{~m} \\
1\end{array}$ & \\
\hline 2 & $\begin{array}{l}\text { Figures } E \text { coli bacteria } \\
\text { in food } 0 / \mathrm{g} \text { sample } \\
\text { food }\end{array}$ & & 0 & & 0 & & 0 & & 0 & & 0 \\
\hline 3 & $\begin{array}{c}\text { Total heavy metal } \\
\text { content does not } \\
\text { exceed the threshold. } \\
\text { - Iron } \\
\text { - Zinc } \\
\text { - Aluminium } \\
\text { - Barium } \\
\text { - Copper } \\
\text { - Nickel } \\
\text { - Lead }\end{array}$ & $\begin{array}{l}- \\
- \\
- \\
- \\
- \\
-\end{array}$ & $\begin{array}{l}- \\
- \\
- \\
- \\
- \\
- \\
-\end{array}$ & $\begin{array}{l}- \\
- \\
- \\
- \\
- \\
- \\
-\end{array}$ & $\begin{array}{l}- \\
- \\
- \\
- \\
- \\
- \\
-\end{array}$ & $\begin{array}{c}0,4 \\
0 \\
0,25 \\
0 \\
0 \\
0 \\
0\end{array}$ & & $\begin{array}{c}0,45 \\
0 \\
0,31 \\
0,81 \\
0 \\
0 \\
0\end{array}$ & & $\begin{array}{c}0,38 \\
0 \\
0,24 \\
0,79 \\
0 \\
0 \\
0\end{array}$ & \\
\hline 4 & $\begin{array}{l}\text { The amount of } \\
\text { pesticide residue } \\
\text { content does not } \\
\text { exceed the threshold }\end{array}$ & & 0 & & 0 & & 0 & & 0 & & 0 \\
\hline
\end{tabular}




\section{CONCLUSIONS AND SUGGESTIONS}

\section{A. Conclusions}

1. Quality food at two (2) air transport industry catering services either because it has no content of $\mathrm{E}$ coli, heavy metals and pesticides.

2. The quality of food at a party organizer catering less well because they contain $\mathrm{E}$ coli, iron, aluminum and barium.

3. The content of $E$ coli were found in sample drinks at a party as much as the business manager of $240 / 100 \mathrm{ml}$, iron content of between $0.38-0.45$, aluminum between 0.24 to 0.31 , Barium content of between 0.79 to 0,81 .

4. There is a relationship manager of food hygiene monitoring system.

5. There is a relationship with food sanitation supervision system.

6. The physical condition of the kitchen business catering air transportation shows that the location of doors and windows, lighting / ventilation, hand washing facilities, clean water, latrines already meet the standards of airworthiness except the floor and walls are dead angle and less food processing equipment sterilization.

7. The physical condition of the kitchen at catering business do not have a standard airworthiness of all components.

\section{B. Suggestions}

1. To the catering business:

a) In order to implement the monitoring system in the food processing catering business and to cooperate with related parties such as the Department of Health to continue to monitor the implementation of the management of the kitchen.

b) Expected to improve the quality of personal hygiene of the workers in the kitchen, sanitary working environment and the physical condition of the place of business in food processing so as to lead to airworthiness standard conditions.

c) In order to improve the quality in food processing so that the content cannot be found anymore E coli, iron, aluminum and barium on the quality of the food produced.

2. To the catering services of air transportation: In order to maintain the monitoring system and the quality of food processing that already meet airworthiness standards that have been implemented.
3. To the Department of Health: In order to carry out monitoring to every business catering services periodically especially concerning hygiene and sanitation efforts catering.

4. To the Port Health Office: In order to continue to perform periodic monitoring to every catering business under the supervision of relevant port health authority hygiene and sanitation in the catering business.

\section{REFERENCES}

[1] Azwar,A., 1996, Pengantar Administrasi Kesehatan, Edisi Ketiga, Binarupa Aksara, Jakarta.

[2] DepKes RI, 1999, Peraturan Menteri Kesehatan Republik Indonesia No. 304/MenKes/Per/1989 Tentang Persyaratan Kesehatan Rumah Makan dan Restoran dan Petunjuk Pelaksanaannya, Jakarta

[3] _ 2000, Prinsip-prinsip Kerja Sanitasi Makanan, Jakarta

[4] , 2001, Pedoman Penerapan Cara Produksi Makanan Yang Baik, Jakarta.

[5] , 2003, Keputusan Menteri Kesehatan Republik Indonesia No.715/MenKes/SK/V/2003, Tentang Persyaratan Hygiene Sanitasi Jasa Boga, Jakarta

[6] Djajadiningrat, Suklan, 2002, Makanan Kesehatan dan Cathering, Mismar, Jakarta

[7] Entjang, 2000, Ilmu Kesehatan Masyarakat, Penerbit PT. Citra Aditya Bhakti, Bandung.

[8] Ensiklopedia Indonesia, 2002, Gramedia, Jakarta

[9] Handoko, 2004, Manajemen, Andi Press, Yogyakarta

[10] Haryono, 2006, Teknik Pemeriksaan Kualitas Makanan Restoran, Mismar, Jakarta.

[11] Luandberg, D.R., Hygiene and Sanitation, 2001, Boulderest, New York.

[12] Motarjemi, Y. Dan Adam, M., 2004, Dasar-dasar Keamanan Makanan Untuk Petugas Kesehatan, ECG, Jakarta

[13] Mukhtar, 2006, Syarat Hygiene dan Sanitasi Pengelola Dapur, Rineka Cipta, Bandung.

[14] Murti, B, 1996, Penerapan Metode Statistik Non Parametrik Ilmi-ilmu Kesehatan, PT. Gramedia, Jakarta

[15] Purnawijayanti Hiasinta, 2001, Sanitasi Hygiene dan Keselamatan Kerja Dalam Pengolahan Makanan, Kanisius, Jakarta

[16] Republik Indonesia, Depkes, 2003, Keputusan Menteri Kesehatan R.I Nomor : 715/Menkes/SK/V/2003, Tentang Persyaratan Hygiene Sanitasi Jasa Boga, Jakarta

[17] Retno, 2002, Hygiene dan Sanitasi Jasa Boga, Gramedia, Jakarta

[18] Riduwan, 2004, Metode dan Teknis Menyusun Tesis, Alfabeta, Bandung

[19] Sihite, R, 2004, Pengantar Dasar Perhotelan, Gramedia Pustaka Utama, Jakarta

[20] Supraptini dkk, 2003. http://www.ekologi.litbang.depkes.co.id diakses tanggal 14 Januari 2009.

[21] Supardi, Imam dan Sukamto, 1999, Mikrobiologi Dalam Pengolahan dan Keamanan Pangan, Alumni, Jakarta

[22] Sugiyono, 2005, Statistika Untuk Penelitian, CV. Alfabeta, Bandung 